\title{
Phoebe nicobarica (Lauraceae) - a new species from Andaman \& Nicobar Islands, India
}

\author{
Rasingam L. ${ }^{1 *}$, Singh L.J. ${ }^{2} \&$ K. Karthigeyan ${ }^{3}$ \\ ${ }^{1}$ Botanical Survey of India, Deccan Regional Centre, Hyderabad, Telangana - 500 095, India \\ ${ }^{2}$ Botanical Survey of India, Andaman \& Nicobar Regional Centre, Haddo, Port Blair, Andaman and Nicobar Islands - 744 102, India \\ ${ }^{3}$ Botanical Survey of India, Central National Herbarium, P.O. Botanic Garden, Howrah, West Bengal - 711 103, India \\ *E-mail: rasingam@gmail.com
}

\begin{abstract}
Phoebe nicobarica sp. nov. (Lauraceae) is described from the Great Nicobar Island of Andaman \& Nicobar Islands, India. The new species is closely related to Phoebe macrophylla Blume and Phoebe kunstleri Gamble, but differs by the white glaucous lower leaf surface, indumentum type and fruit shape.
\end{abstract}

Keywords: Bay Islands, Evergreen Forest, Flora, Novelty, Tropics.

\section{Introduction}

Phoebe Nees is a genus of evergreen trees and shrubs belonging to the family Lauraceae distributed in tropical and subtropical Asia with c. 75 species (POWO, 2019). Santapau and Henry (1973) reported nine species from India and subsequently three more species were described from Arunachal Pradesh (Gangopadhyay, 2006; Gangopadhyay \& Sarmah, 2007) and Western Ghats (Gangopadhyay, 2009). The occurrence of this genus in the Andaman \& Nicobar Islands was not known until Rasingam (2015) reported Phoebe lanceolata (Nees) Nees from Little Andaman Island.

While working on the flora of Little Andaman Island, the senior author came across some unidentified specimens collected by D.K. Hore from Laful north of Great Nicobar Island at the herbarium of the Botanical Survey of India, Andaman \& Nicobar Regional Centre (PBL), Port

Received: 02.12.2020; Revised \& Accepted: 23.03.2021

Published Online: 30.06 .2021
Blair. After critical examination of all the specimens available at PBL and consultation of the relevant literature (Kurz, 1877; Hooker, 1886; Gamble, 1912; Ridley, 1924; Backer \& Bakhuizen van den Brink, 1963; Kochummen, 1989), we found that this species is closely related to Phoebe macrophylla Blume and P. kunstleri Gamble, but differs in many aspects. Hence, it is described here as a species new to science. Further, it is the second addition to the genus Phoebe for the flora of Andaman \& Nicobar Islands. A key to the species occurring on these islands also provided to facilitate identification.

\section{Taxonomic Treatment}

Phoebe nicobarica Rasingam, L.J. Singh \& Karthig., sp. nov.

Figs. 1 \& 2

Phoebe nicobarica is similar to P. macrophylla but differs by its white glaucous, pubescent abaxial leaf surface, sub-glabrous inflorescence and globose to sub-globose fruits, whereas in P. macrophylla the leaves and inflorescences are ferruginous tomentose throughout and the fruits are ellipsoid.

Type: INDIA, Andaman \& Nicobar Islands, Great Nicobar Island, Laful North, 13.06.1981, D.K. Hore 8798 (holo PBL [PBL0005000002!]; iso PBL [PBL0005000003!, PBL0000027258!]).

Medium sized evergreen trees, to $12 \mathrm{~m}$ high; branchlets 5-7 $\mathrm{mm}$ in diam., reddish-brown, terete to sub-terete, pubescent when young, glabrescent on maturity. Leaves simple, alternate or crowded at the tip, obovate, rarely elliptic, 13-29 × 5.5-12 $\mathrm{cm}$, acuminate at apex, acumen $0.5-1 \mathrm{~cm}$ long, 


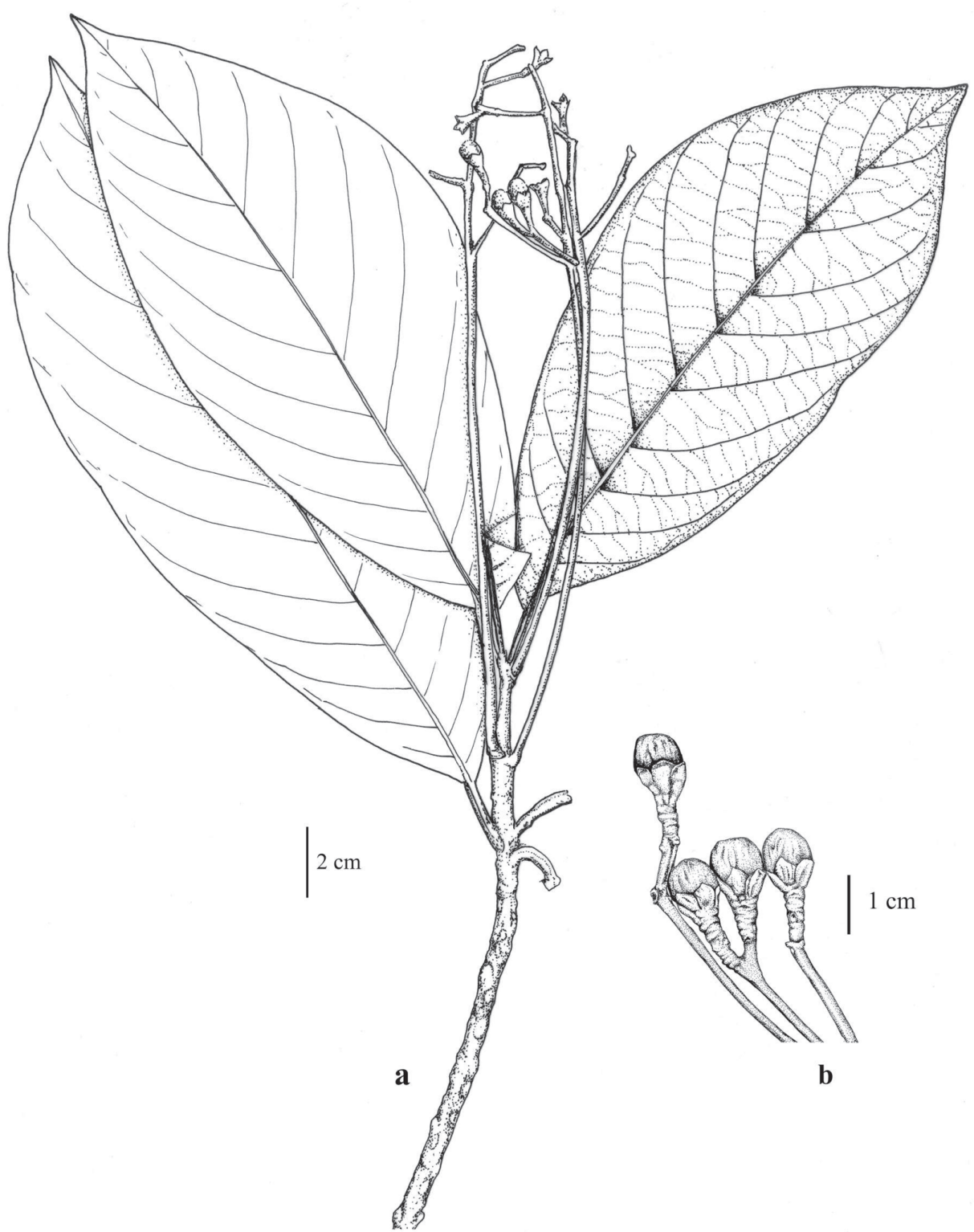

Fig. 1. Phoebe nicobarica Rasingam, L.J.Singh \& Karthig.: a. Fruiting branch; b. Fruits (from D.K. Hore 8798; drawn by D.K. Shah).

cuneate to acute at base, glabrous above, white glaucous and pubescent beneath; hairs white; midrib prominent beneath, sunken above, lateral nerves 9-13 pairs, prominent beneath, sunken above, arcuate, forming loops near margin; tertiary nerves scalariform, prominent beneath, faint above; petioles 1.5-2.2 cm long, canaliculate, reddish-brown, swollen at base, glabrous. Infructescences axillary panicles, reddish-brown, up to $28 \mathrm{~cm}$ long, branched in the distal third, glabrous to sub-glabrous; peduncles up to $22 \mathrm{~cm}$ long, terete. Tepals persistent in fruit, appressed to the berry, outer tepals c. $5 \mathrm{~mm}$ long, oblong-elliptic, obtusely acute at apex, overlapping and forming a cup, faintly 3-nerved, puberulous, ciliate along margin; inner ones slightly bigger than the outer, broadly ovate, obtusely acute at apex; fruiting pedicels up to $1 \mathrm{~cm}$ long, wrinkled, thickened. Fruit a berry, green when young, globose to sub- 


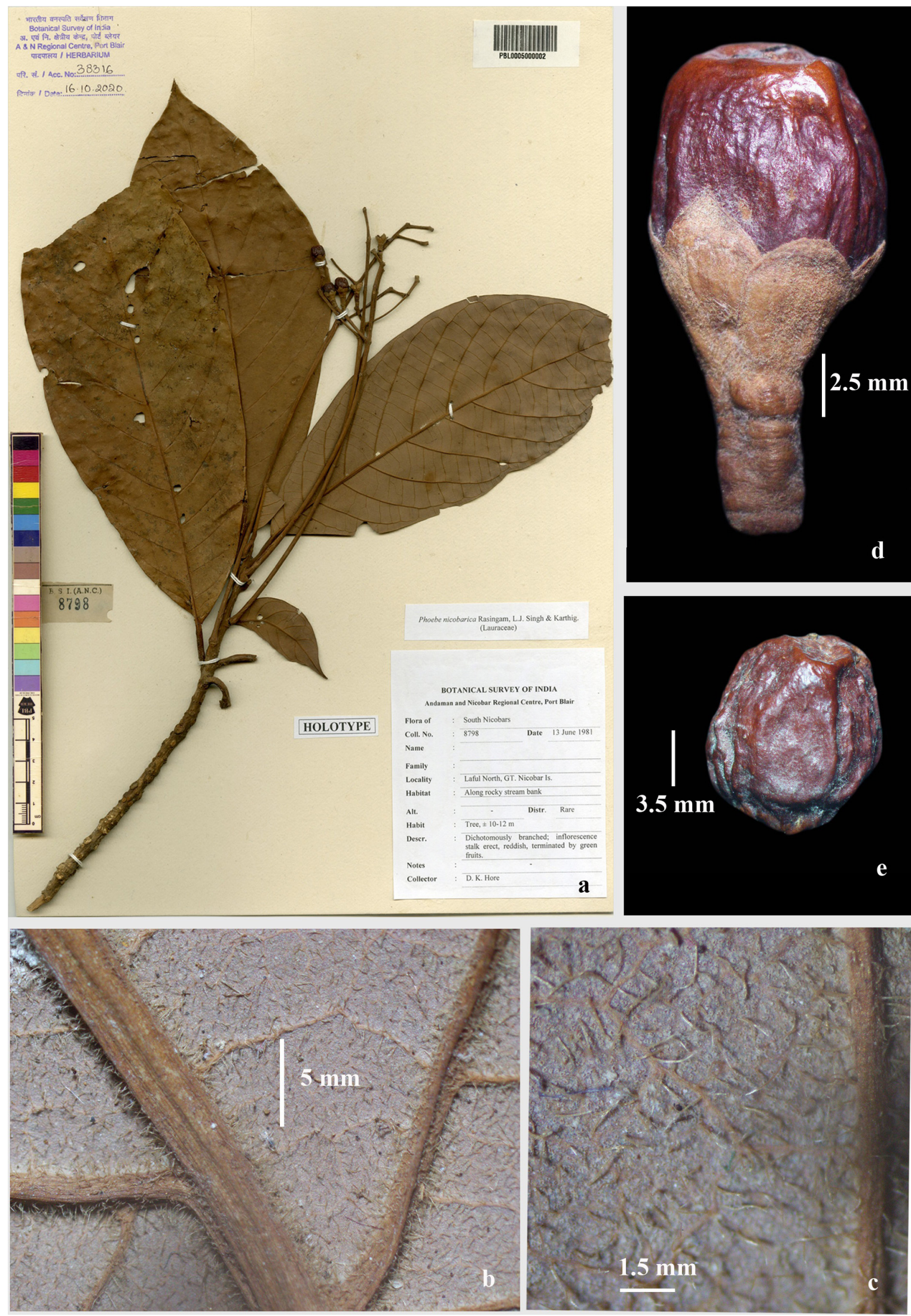

Fig. 2. Phoebe nicobarica Rasingam, L.J.Singh \& Karthig.: a. Image of holotype; b. \& c. Abaxial leaf surface showing white glaucous hairs; d. Fruit with cup shaped tepals; e. Fruit (from D.K. Hore 8798; photos by Gautam Anuj Ekka). 
Table 1. Morphological comparison of Phoebe nicobarica, P. macrophylla and P. kunstleri

\begin{tabular}{|l|l|l|l|}
\hline Characters & $\begin{array}{l}\text { P. nicobarica Rasingam, } \\
\text { L.J.Singh \& Karthig. }\end{array}$ & P. macrophylla Blume & P. kunstleri Gamble \\
\hline Leaf indumentum & $\begin{array}{l}\text { White glaucous beneath, } \\
\text { sparsely pubescent; } \\
\text { hairs whitish }\end{array}$ & $\begin{array}{l}\text { Densely ferruginous } \\
\text { tomentose beneath; } \\
\text { hairs reddish-brown }\end{array}$ & Minutely puberulous \\
\hline Leaf base & Cuneate or acute & Cuneate or attenuate & Attenuate \\
\hline $\begin{array}{l}\text { Infructescence } \\
\text { indumentum }\end{array}$ & Glabrous to sub-glabrous & $\begin{array}{l}\text { Densely ferruginous } \\
\text { tomentose }\end{array}$ & Puberulous \\
\hline Tepal indumentum & Pubescent & $\begin{array}{l}\text { Densely ferruginous } \\
\text { tomentose }\end{array}$ & Tomentose \\
\hline Fruits & $\begin{array}{l}\text { Globose to sub-globose, } \\
0.5-1.2 \times c .1 \mathrm{~cm}, \text { wrinkled }\end{array}$ & $\begin{array}{l}\text { Ovoid-ellipsoid, } c .2 \times 1 \mathrm{~cm}, \\
\text { smooth }\end{array}$ & $\begin{array}{l}\text { Ovoid, } c .1 .5 \times 1 \mathrm{~cm}, \\
\text { wrinkled }\end{array}$ \\
\hline
\end{tabular}

globose, $0.5-1.2 \times c .1 \mathrm{~cm}$, flat at the top, glabrous.

Flowering \& Fruiting: Flowering unknown and fruiting from July.

Distribution: India: Andaman \& Nicobar Islands, Great Nicobar Island.

Etymology: The species is named after the type locality Great Nicobar Island, the southernmost and largest Island of the Nicobar group of Islands, India.

Notes: Phoebe nicobarica is also similar to another Malaysian species P. kunstleri by its leaf shape and size but differs mainly by indumentum types, glaucous nature of the abaxial leaf surface and fruit shape.

\section{Key to the Phoebe species occurring in Andaman \& Nicobar Islands}

1. Leaves obovate, rarely elliptic, pubescent beneath; fruiting tepals pubescent

P. nicobarica

1. Leaves lanceolate or elliptic-lanceolate, glabrous; fruiting tepals glabrous

P. lanceolata

\section{Acknowledgements}

The authors are grateful to Dr. A. A. Mao, Director, Botanical Survey of India, Kolkata and to Dr. P.V.
Prasanna, Scientist G \& Head of Office, Botanical Survey of India, Deccan Regional Centre, Hyderabad for facilities and encouragement. They are also thankful to Mr. D. K. Shah, Artist, Central National Herbarium, Howrah for the line drawing and Mr. Gautam Anuj Ekka, Botanical Assistant, Andaman \& Nicobar Regional Centre, Port Blair, for technical support.

\section{Literature Cited}

BACKER C.A. \& R.C. BAKHUIZEN VAN DEN BRINK 1963. Flora of Java. Volume 1. N.V.P. NoordhoffGroningen, The Netherlands.

GAMBLE J.S. 1912. Materials for a Flora of the Malayan Peninsula, No 22. Journal of Asiatic Society Bengal, Pt. 2, Nat. Hist. 75: 1-204.

GANGOPADHYAY M. 2006. Notes on the Family Lauraceae from India and its adjoining countries I, Bulletin Botanical Survey of India 48(1-4): 103-156.

GANGOPADHYAY M. 2009. Three new taxa in Lauraceae from India. Bangladesh Journal of Plant Taxonomy 16(2): 141-149. https://doi.org/10.3329/ bjpt.v16i2.3926

GANGOPADHYAY M. \& A. SARMAH 2007. A new species of the genus Phoebe Nees (Lauraceae) from North-East India. Bangladesh Journal of Plant Taxonomy 14(2): 163-165. https://doi.org/10.3329/bjpt.v14i2.534

HOOKER J. D. 1886. Lauraceae. In: HOOKER J.D. (ed.), Flora of British India. Volume 5. L. Reeve \& Co., Ltd., London. pp. 116-189. 
KOCHUMMEN K.M. 1989. Lauraceae. In: NG F.S.P. (ed.), Tree Flora of Malaya. Volume 4. Longman, Malaysia. pp. 98-178.

KURZ S. 1877. Forest Flora of British Burma. Volume 2. Office of the Superintendent of Government Printing, Calcutta.

POWO 2019. Plants of the World Online. Facilitated by the Royal Botanic Gardens, Kew. Available at: http:// www.plantsoftheworldonline.org/ (Accessed on 15.03.2021).
RASINGAM L. 2015. Five new additions to the flora of Andaman \& Nicobar Islands, India. Journal of Threatened Taxa 7(3): 7037-7041. http://dx.doi.org/10.11609/ JoTT.o3537.7037-41

RIDLEY H. N. 1924. The Flora of the Malay Peninsula Volume 3. L. Reeve \& Co. Ltd., London.

SANTAPAU H. \& A.N. HENRY 1973. A dictionary of the flowering plants in India. CSIR, New Delhi. 